\title{
АВТОМАТИЗАЦІЯ РОБОЧОГО МІСЦЯ ЛІКАРЯ-БІОХІМІКА ГЕНЕТИКА
}

\author{
В. 3. Стецюк, А. Й. Савицький, Т. П. Іванова ${ }^{1}$, Н. В. Ольхович ${ }^{1}$, \\ С. П. Кир'яченко ${ }^{1}$, А. О. Горбенко, Р. Г. Ковтунович \\ Конструкторське бюро інформаційних систем Національного технічного \\ університету України «Київський політехнічний інститут» \\ Національна дитяча спеціалізована лікарня "ОХМАТДИТ»

\begin{abstract}
У лабораторії медичної генетики НДСЛ «ОХМАТДИТ» для виявлення достовірності результатів лабораторних досліджень та контролю кількості і частоти виникнення помилок, здійснюють внутрішньолабораторний контроль якості. 3 метою оцінки результатів вимірювань зразків та усунення неприпустимих аналітичних помилок розроблено та впроваджено програмне забезпечення, що дозволяє будувати калібрувальний графік та обробляти результати біохімічного дослідження активності лізосомних фрерментів.
\end{abstract}

Ключові слова: внутрішньолабораторний контроль якості, калібрувальний графрік, активність лізосомних ферментів, достовірність біохімічних досліджень, лабораторія медичної генетики.

\section{АВТОМАТИЗАЦИЯ РАБОЧЕГО МЕСТА ВРАЧА-БИОХИМИКА ГЕНЕТИКА}

\author{
В. 3. Стецюк, А. Й. Савицький, Т. П. Иванова ${ }^{1}$, Н. В. Ольхович ${ }^{1}$, \\ С. П. Кирьяченко ${ }^{1}$, А. О. Горбенко, Р. Г. Ковтунович \\ Конструкторское бюро информационных систем национального технического \\ университета Украины «Киевский политехнический институт» \\ Национальная детская специализированная больница “ОХМАТДЕТ» ${ }^{1}$
}

В лаборатории медицинской генетики НДСБ «ОХМАТДЕТ» для выявления достоверности результатов лабораторных исследований и контроля количества и частоты возникновения ошибок, осуществляют внутрилабораторный контроль качества. С целью оценки результатов измерений образцов и устранения недопустимых аналитических ошибок разработано и внедрено программное обеспечение, позволяющее строить калибровочный график и обрабатывать результаты биохимического исследования активности лизосомных ферментов.

Ключевые слова: внутрилабораторный контроль качества, калибровочный график, активность лизосомальных ферментов, достоверность биохимических исследований, лаборатория медицинской генетики.

\section{AUTOMATION WORKPLACE OF A DOCTOR BIOCHEMIST ON GENETICS}

\author{
V. Z. Stetsyuk, A. Y. Savytskyi, T. P. Ivanova ${ }^{1}$, N. V. Olkhovych ${ }^{1}$, \\ S. P. Kyryachenko ${ }^{1}$, A. O. Horbenko, R. H. Kovtunovych \\ Design Office of Information Systems of the National Technical University of Ukraine \\ "Kyiv Polytechnic Institute» \\ National Children's Specialized Hospital "OKHMATDYT» ${ }^{1}$

\begin{abstract}
In the laboratory of medical genetics NCSH «OKHMATDYT» to identify the reliability of laboratory results and control the number and frequency of errors, carry out internal quality control. In order to evaluate the results of measurements of samples and eliminate harmful analytical errors developed and introduced software that allows you to build a calibration curve and process the results of biochemical research activity of lysosomal enzymes.
\end{abstract}

Key words: internal quality control, calibration curve, the activity of lysosomal enzymes, the accuracy of the biochemical research laboratory of medical genetics.

Вступ. Питання якості клінічних лабораторних досліджень є сьогодні найактуальнішим у галузі лабораторної медицини. Для контролю кількості і частоти виникнення помилок, а також для

(C) В. 3. Стецюк, А. Й. Савицький, Т. П. Іванова та ін. 
здійснення своєчасних дій, спрямованих на їх корекцію, існує внутрішньолабораторний контроль якості. Він здійснюється на усіх етапах лабораторного процесу, починаючи 3 визначення потреб клініцистів, включає етапи отримання біоматеріалу і визначення кількості аналізованих речовин і закінчується на етапі видачі висновку.

Мета роботи: автоматизація та оптимізація внутрішньолабораторного контролю якості шляхом створення спеціалізованого програмного забезпечення, що дозволяє будувати калібрувальний графік та обробляти результати біохімічного дослідження активності лізосомних ферментів для застосування в практиці лабораторії медичної генетики.

Матеріал і методи дослідження. Контроль якості аналітичного етапу лабораторного дослідження - це насамперед оцінка результатів вимірювань зразків. Але крім самого аналізу існує ще маса необхідних процедур, які потребують контролю. Якість виконання лабораторного дослідження багато в чому визначається правильно обраною та виконаною методикою оцінки отриманих під час роботи з фотометричним обладнанням результатів. Вона грунтується на використанні градуювального графіка, факторів перерахунку, а також формули, що враховує значення абсорбції (екстинкції) або флуоресценції і концентрації стандартних проб, які обробляються паралельно 3 дослідними в однакових із ними умовах.

Для зменшення похибок, пов'язаних з можливими змінами неконтрольованих параметрів, необхідно проводити процедуру калібрування перед кожною серією аналізів досліджуваних зразків. Тому, для оптимізації процесу побудови калібрувального графіка і оцінки правильності і достовірності проведених біохімічних досліджень, нами було розроблено автоматизовану систему (програмне забезпечення) побудови калібрувального графіка та обробки результатів біохімічного дослідження активності лізосомних ферментів для застосування в практиці лабораторії медичної генетики.

Програмне забезпечення реалізоване на мові програмування Java за допомогою патернів modelview-controller (MVC) та data access object (DAO), для формування певної структури та ієрархії даних, а також для їх зберігання використовується компактна вбудована реляційна база даних SQLite. Програма використовує стандартні бібліотеки јаvа та відкриту бібліотеку jfreechart, що дозволяє візуалізувати градуювальний графік. А сама граду- ювальна (калібрувальна) крива розраховується як лінійний тренд за допомогою методу найменших квадратів, вона відображає тісну залежність між абсорбцією (А), що називається також оптичною щільністю (D) або екстинкцією (Е) (або, в окремих випадках, інтенсивністю випромінення світла, зокрема, під час здійснення полум'яної фотометрії, флуориметрії), та концентрацією (C) речовини в серіях стандартних розчинів. Програмний продукт може бути запущений на комп'ютері з будь-якою архітектурою, де встановлена віртуальна јаvамашина (JRE-7).

Результати й обговорення. Розроблене програмне забезпечення має назву «Автоматизоване робоче місце лікаря-біохіміка генетика». Програма має простий інформативний інтерфейс зі зручною графічною оболонкою (рис. 1) та модуль автоматичної перевірки коректності введених даних, що зводить до мінімуму кількість помилок. Така система дозволяє оптимізувати роботу лікарів лабораторії, та, як наслідок, зменшити ймовірність помилки на етапі аналізу лабораторних досліджень.

Програмний продукт дозволяє виконувати такі дії:

Створення, редагування, видалення та перегляд проектів (окремих серій аналізів досліджуваних зразків).

Додавання до вже існуючого проекту будь-якої кількості зразків та калібрувальних точок (стандартних проб).

Збереження введених даних, розрахунок результатів біохімічного дослідження залежно від обраних параметрів ферменту та матеріалу.

Побудову калібрувального графіка та його налаштування, наближення та виділення окремих ділянок та збереження на комп'ютері чи друк на принтері цього графіка.

Друк результатів роботи 3 програмою, або їх збереження у вигляді зображення.

Слід відзначити простоту користування програмою, тобто немає необхідності в спеціальній підготовці лікаря для виконання вищеописаних дій.

Висновок. Програмний продукт «Автоматизоване робоче місце лікаря-біохіміка генетика» протестований, оптимізований та впроваджений в лабораторії медичної генетики НДСЛ «Охматдит» MO3 України. Ефективність впровадження: забезпечити високу якість процесу лабораторної діагностики великої групи спадкових метаболічних захворювань - лізосомних хвороб накопичення, i значно покращити якість надання медичної допомоги цим хворим. 


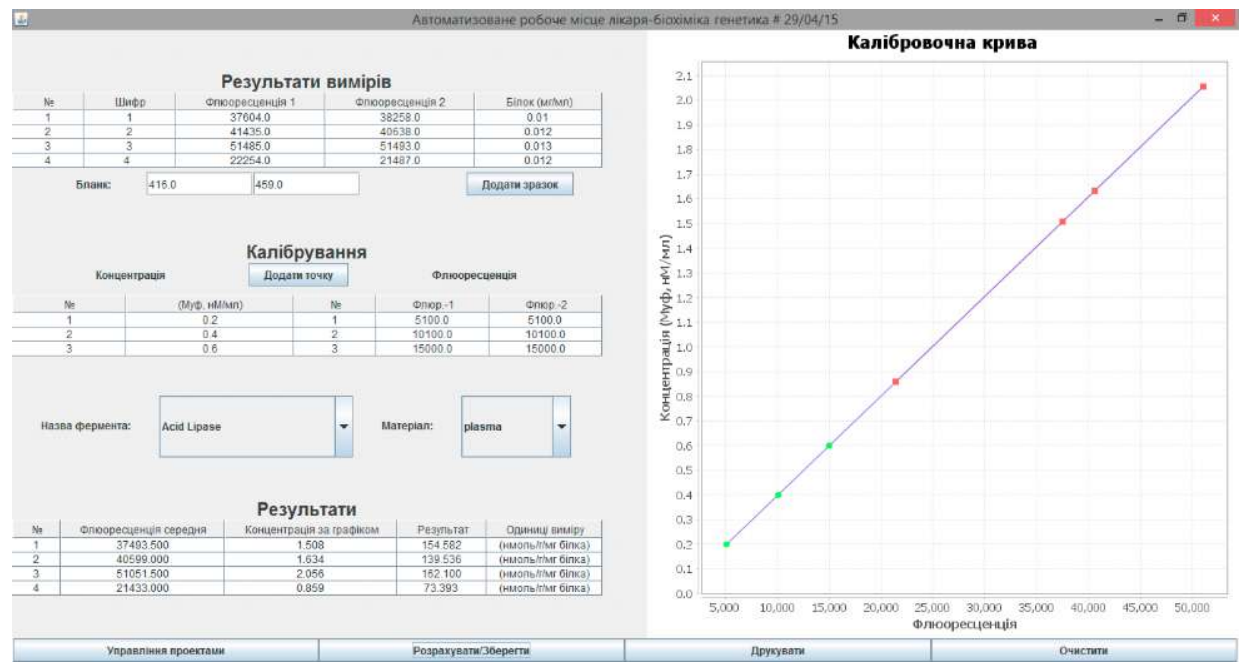

Puc. 1. Інтерфейс програми «Автоматизоване робоче місце лікаря-біохіміка генетика».

АВТОМАТИЗАЦІЯ РОБОЧОГО МІСЦЯ ЛІКАРЯ-БІОХІМІКА ГЕНЕТИКА

\begin{tabular}{|c|c|c|c|c|c|c|c|c|}
\hline ПІБ & $\begin{array}{c}\text { Науковий } \\
\text { ступінь }\end{array}$ & \begin{tabular}{|c|} 
Вчене \\
звання \\
\end{tabular} & $\begin{array}{l}\text { Місце } \\
\text { роботи }\end{array}$ & Посада & $\begin{array}{c}\text { Службова } \\
\text { адреса }\end{array}$ & Телефон & Факс & $\begin{array}{c}\text { Електронна } \\
\text { пошта } \\
\end{array}$ \\
\hline $\begin{array}{l}\text { Стецюк } \\
\text { Валерій 3а- } \\
\text { харович }\end{array}$ & & & \begin{tabular}{|l|} 
НТУУ \\
«КПІ», \\
Інститут \\
кіберне- \\
тики НАН \\
України \\
\end{tabular} & $\begin{array}{l}\text { Завідувач лабора- } \\
\text { торії інноваційних } \\
\text { технологій, завіду- } \\
\text { ючий відділенням }\end{array}$ & $\begin{array}{l}\text { м. Київ, } \\
\text { пр-т Пере- } \\
\text { моги, } 37\end{array}$ & $\begin{array}{l}(044) 406- \\
80-05\end{array}$ & $\begin{array}{l}(044) 454- \\
98-45\end{array}$ & $\begin{array}{l}\text { valeriy.sys- } \\
\text { tems@gmail.ru }\end{array}$ \\
\hline $\begin{array}{l}\text { Савицький } \\
\text { Артем Ио- } \\
\text { сипович }\end{array}$ & \begin{tabular}{|l} 
Канди- \\
дат тех- \\
нічних \\
наук \\
\end{tabular} & Доцент & $\begin{array}{l}\text { НТУУ } \\
\text { «КПІ» }\end{array}$ & $\begin{array}{l}\text { Директор КБ IC } \\
\text { НТУУ «КПІ» }\end{array}$ & $\begin{array}{l}\text { м. Київ, } \\
\text { пр-т Пере- } \\
\text { моги, } 37\end{array}$ & $\begin{array}{l}(044) 236- \\
41-22\end{array}$ & $\begin{array}{l}(044) 454- \\
98-45\end{array}$ & $\begin{array}{l}\text { a.savitskiy@ } \\
\text { kpi.ua }\end{array}$ \\
\hline $\begin{array}{l}\text { Іванова } \\
\text { Тетяна } \\
\text { Павлівна }\end{array}$ & $\begin{array}{l}\text { Канди- } \\
\text { дат ме- } \\
\text { дичних } \\
\text { наук } \\
\end{array}$ & & \begin{tabular}{|l|} 
НДСЛ \\
«Охмат- \\
дит» МО3 \\
України \\
\end{tabular} & $\begin{array}{l}\text { Заступник головно- } \\
\text { го лікаря НДСЛ } \\
\text { «Охматдит» }\end{array}$ & $\begin{array}{l}\text { м. Київ, } \\
01135, \text { вул. } \\
\text { Чорновола } \\
28 / 1\end{array}$ & $\begin{array}{l}(044) 236- \\
01-92\end{array}$ & $\begin{array}{l}(044) 236- \\
01-92\end{array}$ & $\begin{array}{l}\text { ohmadet-ash@ } \\
\text { mail.ru }\end{array}$ \\
\hline $\begin{array}{l}\text { Ольхович } \\
\text { Наталія Ві- } \\
\text { кторівна }\end{array}$ & \begin{tabular}{|l|} 
Канди- \\
дат біо- \\
логічних \\
наук
\end{tabular} & & $\begin{array}{l}\text { НДСЛ } \\
\text { «Охмат- } \\
\text { дит» МО3 } \\
\text { України }\end{array}$ & $\begin{array}{l}\text { Завідувач лабо- } \\
\text { раторії медичної } \\
\text { генетики НДСЛ } \\
\text { «Охматдит» }\end{array}$ & $\begin{array}{l}\text { м. Київ, } \\
01135, \text { вул. } \\
\text { Чорно- } \\
\text { вола 28/1 } \\
\text { НДСЛ }\end{array}$ & $\begin{array}{l}(044) 236- \\
17-36\end{array}$ & $\begin{array}{l}(044) 236- \\
01-19\end{array}$ & $\begin{array}{l}\text { nolhovich@ } \\
\text { gmail.com }\end{array}$ \\
\hline $\begin{array}{l}\text { Киряченко } \\
\text { Світлана } \\
\text { Петрівна }\end{array}$ & \begin{tabular}{|l|} 
Канди- \\
дат біо- \\
логічних \\
наук
\end{tabular} & & $\begin{array}{l}\text { НМАПО } \\
\text { ім. П. Л. } \\
\text { Шупика }\end{array}$ & $\begin{array}{l}\text { Завідуюча } \\
\text { молекулярно- } \\
\text { генетичної лабора- } \\
\text { торії } \\
\text { д.з. «Референс- } \\
\text { центр } з \text { молекуляр- } \\
\text { ної діагностики Мі- } \\
\text { ністерства охорони } \\
\text { здоров'я України» }\end{array}$ & $\begin{array}{l}\text { м. Київ, } \\
04112, \text { До- } \\
\text { рогожиць- } \\
\text { ка, } 9\end{array}$ & $\begin{array}{l}(044) 205- \\
48-13\end{array}$ & & $\begin{array}{l}\text { genetic2007@ } \\
\text { ukr.net }\end{array}$ \\
\hline $\begin{array}{l}\text { Ковтунович } \\
\text { Роман Ген- } \\
\text { надійович }\end{array}$ & & & $\begin{array}{l}\text { НТУУ } \\
\text { «КПІ» }\end{array}$ & $\begin{array}{l}\text { Студент ФІОТ, } \\
\text { кафедра ОТ }\end{array}$ & $\begin{array}{l}\text { м. Київ, } \\
\text { пр-т Пере- } \\
\text { моги, } 37\end{array}$ & $\begin{array}{l}(098) 774- \\
27-95\end{array}$ & & $\begin{array}{l}\text { kov2novych@ } \\
\text { gmail.com }\end{array}$ \\
\hline \begin{tabular}{l|} 
Горбенко \\
Артем Оле- \\
гович
\end{tabular} & & & $\begin{array}{l}\text { НТУУ } \\
\text { «КПІ» }\end{array}$ & $\begin{array}{l}\text { Студент ФІОТ, } \\
\text { кафедра ОТ }\end{array}$ & $\begin{array}{l}\text { м. Київ, } \\
\text { пр-т Пере- } \\
\text { моги, } 37\end{array}$ & $\begin{array}{l}(050) 632- \\
76-47\end{array}$ & & $\begin{array}{l}\text { horbenko@ } \\
\text { email.ua }\end{array}$ \\
\hline
\end{tabular}




\section{Література}

1. Центр метаболических заболеваний НДСБ «ОХМАТДЕТ». URL: http://www.ohmatdet-metabolic.org.ua/.

2. Документація по класах, інтерфейсах та методах Java. URL: http://www.oracle.com/, http://java.com/.

3. Відкрита бібліотека jfreechart. URL: http://www.jfree. org/.
4. Реалізація шаблону проектування DAO. URL: http:// www.dokwork.ru/2014/02/daotalk.html.

5. Узагальнений шаблон проектування MVC. URL: http://rsdn.ru/article/patterns/generic-mvc.xml.

6. База даних SQLite. URL: http://www.sqlite.org/. 